STUDIA Z PRAWA WYZNANIOWEGO

Tom $23-2020$

DOI: https://doi.org/10.31743/spw.7798

ANNA TUNIA*

\title{
WPŁYW BRAKU REJESTRACJI MAŁŻEŃSTWA ZAWARTEGO W FORMIE WYZNANIOWEJ NA BEZPIECZEŃSTWO OBROTU PRAWNEGO
}

\section{Streszczenie}

Przedmiotem artykułu jest zagadnienie dotyczące wpływu braku realizacji jednej z przesłanek koniecznych zawarcia małżeństwa w formie wyznaniowej, jaką jest sporządzenie aktu małżeństwa zawieranego w formie wyznaniowej na bezpieczeństwo obrotu prawnego. $\mathrm{W}$ tym celu $\mathrm{w}$ artykule przeanalizowano istotne elementy tej przesłanki, którymi są prawidłowo sporządzone i terminowo doręczone dokumenty stanowiące podstawę sporządzenia aktu małżeństwa w USC, a następnie ukazano możliwe reakcje organu administracji stanu cywilnego w związku z niedopełnieniem poszczególnych elementów tej przesłanki zawarcia małżeństwa. W dalszej części artykułu odniesiono się do konkretnych skutków niesporządzenia aktu małżeństwa w formie wyznaniowej, przedstawiając sytuacje, w których małżonkowie i inne osoby uczestniczące w obrocie prawnym w związku z zawartym małżeństwem nie będą mogły korzystać z praw (i obowiązków), które powstałyby, gdyby kierownik USC sporządził konstytuujący ten związek - akt małżeństwa. Podniesiono też uwagi de lege ferenda dotyczące zmiany obecnych przepisów dotyczących zawierania małżeństwa w formie wyznaniowej, która pozwoli na zapewnienie bezpieczeństwa obrotu prawnego, niwelując w wielu przypadkach szkody i krzywdy niematerialne rodzące się z niezawarcia małżeństwa.

Słowa kluczowe: bezpieczeństwo; obrót prawny; małżeństwo; organ administracji stanu cywilnego; zaświadczenie; akt małżeństwa; rejestr stanu cywilnego

$* * * * *$

* Dr hab., prof. KUL, Katedra Prawa Wyznaniowego, Wydział Prawa, Prawa Kanonicznego i Administracji, Katolicki Uniwersytet Lubelski Jana Pawła II, Al. Racławickie 14, 20-950 Lublin, e-mail: atunia@kul.pl. ORCID 0000-0002-7703-0828. 


\section{UWAGI WSTĘPNE}

Rejestracja małżeństw zawieranych w formie wyznaniowej jest zagadnieniem o charakterze administracyjnoprawnym ${ }^{1}$ wiążącym się z usankcjonowaniem statusu prawnego osoby fizycznej w związku z zawartym przez nią związkiem małżeńskim. Zawarcie małżeństwa stanowi bowiem jedno ze zdarzeń kształtujących stan cywilny osoby fizycznej, na który wpływ mają zdarzenia naturalne, czynności prawne, orzeczenia sądowe lub decyzje administracyjne. Stanem cywilnym jest zaś sytuacja prawna osoby, wyrażona przez cechy indywidualizujące ją², która stwierdzana jest przez kierownika USC w akcie stanu cywilnego ${ }^{3}$.

Zawarcie małżeństwa jest czynnością prawną, której skuteczne dokonanie wymaga spełnienia określonych przesłanek koniecznych. Przesłanki te jednak różnicują się w zależności od formy wstąpienia przez strony w związek małżeński - cywilnej lub wyznaniowej. Prawidłowa ich realizacja konieczna jest dla zaistnienia bytu prawnego małżeństwa oraz zagwarantowania bezpieczeństwa obrotu prawnego, w którym małżonkowie ci jak i inne podmioty wywodzące dla siebie określone uprawnienia $\mathrm{z}$ tego związku - będą uczestniczyli.

Przedmiotem niniejszego artykułu będzie kwestia dotycząca braku realizacji jednej z przesłanek koniecznych zawarcia małżeństwa $\mathrm{w}$ formie wyznaniowej oraz ocena wpływu tego braku na bezpieczeństwo obrotu prawnego. W związku z tym w pierwszej kolejności wyjaśnione zostaną podstawowe pojęcia ( $\mathrm{tj}$. bezpieczeństwo, bezpieczeństwo prawne oraz bezpieczeństwo obrotu prawnego) stanowiące podłoże analiz niniejszego opracowania, a następnie poczynione zostaną ustalenia dotyczące charakteru i sposobu realizacji przesłanki wpisu (rejestracji) małżeństwa zawieranego w formie wyznaniowej do rejestru stanu cywilnego oraz kon-

Szadok-Bratuń 2013.

2 Cechą indywidualizującą jest m.in. pozostawanie (lub niepozostawanie) przez osobę w związku małżeńskim. Szerzej: Wojewoda 2014, 17-38; Czajkowska (red.) 2015, 25-29.

Zob. art. 2 ust. 1 ustawy z dnia 28 listopada 2014 r. - Prawo o aktach stanu cywilnego, tekst jedn. Dz. U. z 2018 r. poz. 2224 (dalej: p.a.s.c.). Aktem stanu cywilnego jest wpis o urodzeniu, małżeństwie lub zgonie dokonany w rejestrze stanu cywilnego. Akt ten winien zostać sporządzony przez kierownika USC z chwilą dokonania tego wpisu w rejestrze (art. 2 ust. 2,3 i 4 p.a.s.c.). 
sekwencji jego niedokonania przez zobowiązany do tego podmiot dla bezpieczeństwa sytuacji prawnej uczestników tego obrotu.

\section{BEZPIECZEŃSTWO OBROTU PRAWNEGO JAKO KATEGORIA BEZPIECZEŃSTWA PRAWNEGO}

Bezpieczeństwo jest zagadnieniem, które pozostaje w kręgu zainteresowania wielu dyscyplin naukowych, a sama potrzeba bezpieczeństwa znana jest ludzkości od zarania dziejów. Mówiąc o bezpieczeństwie najczęściej ma się na myśli gwarancje nienaruszalnego przetrwania danego podmiotu oraz swobodę jego rozwoju. Pojęcie to skupia bowiem w sobie dwa elementy, którymi są: brak zagrożenia oraz poczucie pewności ${ }^{4}$.

$\mathrm{Na}$ gruncie prawa nie ma legalnej definicji tego terminu, lecz sytuacja ta nie wynika ze złej woli ustawodawcy, ale związana jest z szerokim zakresem znaczeniowym tego pojęcia. W przestrzeni prawnej termin ten używany jest jednak zawsze $\mathrm{z}$ dookreślającym go rzeczownikiem lub przymiotnikiem wskazującym na jego rodzajowość, bowiem bezpieczeństwo jako stan pozytywny jest wartością, która nie występuje autonomicznie, ale $\mathrm{w}$ powiązaniu z określonym podmiotem lub przedmiotem ${ }^{5}$. Mówi się zatem m.in. o „,bezpieczeństwie prawnym” lub „bezpieczeństwie obrotu prawnego", które - nota bene -wypływa z tego pierwszego.

Przez „bezpieczeństwo prawne” w nauce prawa rozumie się „spójność i stabilność systemu prawa, w tym w szczególności jego wykładni”6. Rozumie się je też jako ,stan osiągany przy pomocy prawa pozytywnego, w którym dobra życiowe człowieka i jego interesy są strzeżone (chronione) w sposób możliwie całkowity i skuteczny"7. Bezpieczeństwo prawne należy jednak odróżnić od pewności prawnej, która wynika z konstytucyjnej zasady zaufania obywateli do państwa i stanowionego prawa ${ }^{8}$, będącej - zdaniem TK - jedną z podstawowych zasad określających stosunki

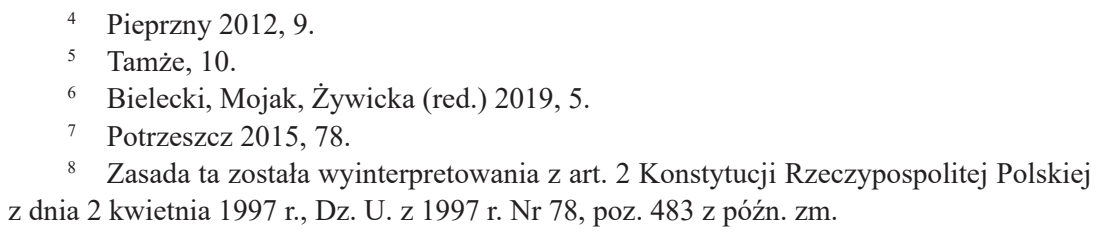

8 Zasada ta została wyinterpretowania z art. 2 Konstytucji Rzeczypospolitej Polskiej z dnia 2 kwietnia 1997 r., Dz. U. z 1997 r. Nr 78, poz. 483 z późn. zm. 
między obywatelem a państwem ${ }^{9}$. W relacji zatem tych dwóch wartości bezpieczeństwo prawne jest celem, zaś pewność prawna jest środkiem do tego celu ${ }^{10}$. Podkreśla się przy tym, że pewność prawa oznacza nie tylko stabilność przepisów prawa, ale przede wszystkim możliwość przewidywania działań organów państwa i związanych z nimi zachowań obywateli ${ }^{11}$.

Pojęcie bezpieczeństwa obrotu prawnego nie ma ustawowego wyjaśnienia. Rozumieć je jednak można jako stan równowagi istniejący pomiędzy ochroną gwarantowaną przez prawo jego podmiotom a zasadą stabilności (pewności) tego obrotu i wynikającym z niej przekonaniem, że podmiot prawa w chwili uzyskania określonego uprawnienia może wywodzić z niego określone dla siebie skutki prawne. Bezpieczeństwo obrotu prawnego zakłada zatem brak zagrożenia dla realizacji praw uczestników tego obrotu wynikających ze stosunków prawnych stanowiących jego przedmiot oraz pewność, że wynikające $\mathrm{z}$ tych stosunków prawa są chronione przez obowiązujący system prawny. W doktrynie podkreśla się, że zasada bezpieczeństwa obrotu prawnego - rozumiana jako stabilność, pewność obrotu prawnego i skuteczność mechanizmów prawnych - pojawia się na etapie stosowania prawa. Nie została ona jednak expressis verbis sformułowana $\mathrm{w}$ żadnym przepisie prawa, ale jej istnienie i znaczenie nie budzi wątpliwości ${ }^{12}$.

\section{CHARAKTER PRZESŁANKI SPORZĄDZENIA AKTU MAŁŻEŃSTWA A BEZPIECZEŃSTWO OBROTU PRAWNEGO}

Na płaszczyźnie prawa o zawieraniu małżeństwa bezpieczeństwo obrotu prawnego wiąże się z gwarancją realizacji przesłanek koniecznych zawarcia małżeństwa, albowiem ich niespełnienie skutkuje niezaistnieniem związku małżeńskiego (matrimonium non existens), a w konsekwencji niemożnością wykonywania wynikających z niego praw i obowiązków mał-

9 Wyrok Trybunału Konstytucyjnego z dnia 14 czerwca 2000 r. (P 3/00), OTK ZU z 2000 r. Nr 5, poz. 138.

10 Szerzej: Potrzeszcz 2013.

11 Bielecki, Mojak, Żywicka (red.) 2019, 5; zob. też: Kochanowski 2007, 99-104.

12 Bielecki, Mojak, Żywicka (red.) 2019, 5. 
żeńskich ${ }^{13}$. Do przesłanek tych - w świetle art. $1 \S 1$ k.r.o. ${ }^{14}$ (określającego cywilną formę zawarcia małżeństwa) - należą: odmienność płci nupturientów, jednoczesna ich obecność podczas składania oświadczeń o zawarciu małżeństwa, złożenie oświadczeń o zawarciu małżeństwa oraz udział uprawnionego podmiotu urzędowego. Przesłanki te obowiązują także w przypadku formy wyznaniowej, choć realizacja niektórych z nich (trzeciej i czwartej) przebiega w inny sposób niż w formie cywilnej ${ }^{15}$. Ponadto poza wymienionymi przesłankami - w przypadku formy wyznaniowej istnieje przesłanka dodatkowa, którą jest sporządzenie aktu małżeństwa.

13 Zob. art. 2 k.r.o. Szerzej: Jędrejek 2019. Wyrok ustalający nieistnienie małżeństwa ma charakter deklaratywny. Nie tworzy on nowego stanu prawnego, a jedynie potwierdza istniejący stan faktyczny, polegający na tym, że określone zdarzenie - pomimo sporządzenia aktu małżeństwa - nie było zawarciem małżeństwa w rozumieniu art. 1. Zob. Dolecki, Sokołowski (red.) 2013.

14 Ustawa z dnia 25 lutego 1964 r. - Kodeks rodzinny i opiekuńczy, tekst. jedn. Dz. U. z 2019 r. poz. 2086.

15 Różnica w odniesieniu do przesłanki złożenia oświadczeń o zawarciu małżeństwa sprowadza się do tego, że w przypadku formy cywilnej strony składają „oświadczenia o wstąpieniu w związek małżeński" (art. 1 § 1 k.r.o.), natomiast w przypadku formy wyznaniowej - zgodnie z nomenklaturą ustawową (art. 1 § 2 k.r.o.) - składają ,oświadczenia woli jednoczesnego zawarcia małżeństwa podlegającego prawu polskiemu przy zawieraniu małżeństwa podlegającego prawu kościoła albo innego związku wyznaniowego", lub - zgodnie z nomenklaturą konkordatową - „oświadczenie woli dotyczące wywarcia przez małżeństwo kanoniczne takich skutków, jakie pociąga za sobą zawarcie małżeństwa zgodnie z prawem polskim" (art. 10 ust. 1 pkt 2). W literaturze przedmiotu oświadczenia te nazywane są ,dodatkowymi oświadczeniami o uzyskaniu skutków cywilnych” (zob. np. Smyczyński 2005, 31-36; Wierciński (red.) 2014), co wskazywałoby, iż oprócz oświadczeń o zawarciu małżeństwa kanonicznego (przysięgi małżeńskiej) strony składają drugie (dodatkowe) oświadczenia o uzyskaniu skutków cywilnych przez to małżeństwo. Nomenklatura ta nie zmienia jednak faktu, iż przedmiotem wskazanych oświadczeń jest wola wstąpienia w związek małżeński, a skutkiem - zawarcie małżeństwa (szerzej np. Mezglewski, Tunia 2007, 120; Mezglewski 2009). Kolejna różnica dotyczy tego, że oświadczenia te mają być złożone wobec uprawnionego podmiotu urzędowego, którym w przypadku formy cywilnej jest kierownik USC lub jego zastępca albo konsul (w sytuacji, gdy małżeństwo zawierane jest przez obywateli polskich zamieszkujących za granicą - art. $1 \S 4$ k.r.o.), zaś w formie wyznaniowej jest nim uprawniony podmiot wyznaniowy, tj. duchowny lub inny uprawniony w danej wspólnocie religijnej szafarz (szerzej nt. pojęcia duchownego zob. np. Zieliński 2011; Tunia 2016). Szersze omawianie tych przesłanek pozostaje jednak poza przedmiotem niniejszego opracowania. W tym aspekcie zob. np. Mezglewski 2011. 
Określający formę cywilną art. $1 \S 1$ k.r.o. stanowi bowiem, że „[m]ałżeństwo zostaje zawarte, gdy mężczyzna i kobieta jednocześnie obecni złożą przed kierownikiem urzędu stanu cywilnego oświadczenia, że wstępują ze sobą w związek małżeński”. Natomiast art. 1 § 2 k.r.o. - określający formę wyznaniową - brzmi: „małżeństwo zostaje również zawarte, gdy mężczyzna i kobieta zawierający związek małżeński podlegający prawu wewnętrznemu kościoła albo innego związku wyznaniowego w obecności duchownego oświadczą wolę jednoczesnego zawarcia małżeństwa podlegającego prawu polskiemu i kierownik urzędu stanu cywilnego następnie sporządzi akt małżeństwa. Gdy zostaną spełnione powyższe przesłanki małżeństwo uważa się za zawarte w chwili złożenia oświadczenia woli w obecności duchownego". Podobne uregulowanie zawiera konkordat ${ }^{16}$, który stanowi, że zawarcie małżeństwa ma zostać wpisane w aktach stanu cywilnego na wniosek przekazany urzędowi stanu cywilnego w terminie pięciu dni od zawarcia małżeństwa (art. 10 ust. 1 pkt 3). Konstytutywny charakter tej przesłanki potwierdza również orzecznictwo $\mathrm{SN}^{17}$.

Przesłanka sporządzenia aktu małżeństwa zawartego w formie wyznaniowej ma zatem charakter odmienny niż w przypadku formy cywilnej, gdzie wymóg ten posiada jedynie walor deklaratoryjny, tj. potwierdzający (dokumentujący) fakt złożonych przez strony oświadczeń o zawarciu małżeństwa ${ }^{18}$. Przyznanie aktowi małżeństwa zawieranego w formie wyznaniowej konstytutywnego charakteru jest jednak zasadne ${ }^{19}$, bowiem pozwala na zachowanie bezpieczeństwa prawnego oraz bezpieczeństwa obrotu prawnego, gwarantując stabilność sytuacji prawnej osób zawierających małżeństwo oraz innych podmiotów wywodzących z tego związ-

16 Konkordat między Stolicą Apostolską i Rzecząpospolitą Polską, podpisany w Warszawie dnia 28 lipca 1993 r., Dz. U. z 1998 r. Nr 51, poz. 318.

17 Wyrok Sądu Najwyższego z dnia 3 marca 2004 r. (III CK 346/02, OSP z 2005 r. Nr 2, poz. 23), którego teza brzmi: „W razie niesporządzenia aktu małżeństwa, mimo spełnienia pozostałych wymogów określonych w art. $1 \S 2$ k.r.o., nie można dochodzić ustalenia istnienia małżeństwa konkordatowego na podstawie art. 189 k.p.c. Rejestracja takiego małżeństwa jest jednym z konstytutywnych wymogów jego zawarcia”. Zob. też: Tadeusz Smyczyński, „Glosa aprobująca do wyroku SN z 3 marca 2004 r., III CK 346/02”, OSP z 2005 r. Nr 2, poz. 23.

18 Por. art. 2 ust. 1 p.a.s.c.

19 Por. Domański 2006, 97. 
ku określone dla siebie skutki prawne. Ustawodawca rodzinny celowo ustanowił szerszy katalog przesłanek koniecznych zawarcia małżeństwa w formie wyznaniowej, by wyeliminować niepewności, jakie mogą powstać w okresie między złożeniem przez nupturientów wobec duchownego oświadczeń o wstąpieniu w związek małżeński a sporządzeniem tego aktu przez kierownika USC. W tym celu posłużył się retroaktywnością skutków prawnych składanych przez strony oświadczeń o zawarciu małżeństwa. Prawo cywilne zezwala bowiem na to, aby określoną czynność prawną - rozumianą jako świadome i zgodne z przepisami prawa zachowanie podmiotu zmierzające do wywołania określonych skutków prawnych mocą składanych oświadczeń woli ${ }^{20}$ - traktować jako mającą moc od określonego $\mathrm{w}$ przepisie prawnym momentu ${ }^{21}$. Oznacza to, że fakty prawne, które nastąpiły w czasie pomiędzy złożeniem przez nupturientów oświadczeń o wstąpieniu w związek małżeński wobec duchownego a momentem sporządzenia aktu małżeństwa w USC mają być oceniane tak jakby w czasie ich zajścia akt ten był już sporządzony (o ile akt ten rzeczywiście będzie sporządzony). A zatem art. $1 \S 2$ k.r.o. wprowadza retroaktywność skutków prawnych oświadczeń składanych przez nupturientów, nakazując wiązać z nimi takie skutki, jakie powstałyby, gdyby akt ten był sporządzony już w chwili ich złożenia przez strony. Sporządzenie aktu małżeństwa wywołuje skutek ex tunc (wsteczny) oznaczający, że małżeństwo $\mathrm{w}$ formie wyznaniowej staje się skuteczne w sferze prawa polskiego nie w momencie sporządzenia tego aktu, lecz od chwili złożenia przez nupturientów oświadczeń o wstąpieniu w związek małżeński² ${ }^{22}$ Jednakże - jak zaznaczono - rzecz wygląda inaczej, jeżeli akt małżeństwa nie zostanie sporządzony. W takiej sytuacji złożone przez strony oświadczenia o wstąpieniu w związek małżeński nie osiągają swych skutków prawnych, co nie pozostaje bez znaczenia dla bezpieczeństwa obrotu prawnego i uczestniczących w nim podmiotów, o czym mowa będzie dalej.

\footnotetext{
20 Nowacki, Tabor 1999, 24.

21 Pietrzykowski 2003, 64, 69-76.

22 Mezglewski, Tunia 2007, 118; A. Gaffke, M. Gaffke 2019, 83.
} 


\section{ELEMENTY PRZESŁANKI KONSTYTUTYWNEJ SPORZĄDZENIA AKTU MAŁŻEŃSTWA}

Sporządzenie przez kierownika USC aktu małżeństwa zawartego w formie wyznaniowej dokonuje się na podstawie odpowiednich dokumentów urzędowo poświadczających fakt złożenia przez strony oświadczeń o wstąpieniu w związek małżeński. Dokumenty te stanowią zatem element przesłanki konstytutywnej sporządzenia tego aktu, bowiem bez ich otrzymania kierownik USC nie może aktu tego sporządzić. Podstawę sporządzenia aktu małżeństwa zawartego w formie wyznaniowej stanowią dokumenty, o których mowa w art. 87 ust. 3 p.a.s.c., a w razie ich braku podstawę tę może stanowić prawomocne postanowienie sądu o sporządzaniu aktu małżeństwa.

Zgodnie z art. 87 ust. 3 p.a.s.c. akt małżeństwa sporządza się na podstawie dwóch (fizycznie odrębnych) zaświadczeń ${ }^{23}$, to jest:

- „Zaświadczenia o braku okoliczności wyłączających zawarcie małżeństwa”, o którym mowa w art. $4^{1}$ k.r.o. (tzw. ,Zaświadczenie o braku przeszkód") ${ }^{24}$, które sporządzane jest w dwóch egzemplarzach przez kierownika USC $\mathrm{w}$ ramach czynności poprzedzających zawarcie małżeństwa; jeden $\mathrm{z}$ tych egzemplarzy wręczany jest nupturientom celem przekazania właściwemu duchownemu jednostki organizacyjnej kościoła albo innego związku wyznaniowego, w której ma być zawarte małżeństwo w formie wyznaniowej ${ }^{25}$ - albowiem zgodnie $\mathrm{z}$ art. $8 \S 1$ k.r.o. duchowny nie może przyjąć oświadczeń woli jednoczesnego zawarcia małżeństwa podlegającego prawu polskiemu składanego przy zawieraniu małżeństwa wyznaniowego, jeżeli nie otrzyma ważnego ${ }^{26}$ zaświadczenia o braku okoliczności wyłączających zawarcie przez strony małżeństwa w formie wyznaniowej, oraz

- „Zaświadczenia stwierdzającego, że oświadczenia o wstąpieniu w związek małżeński zostały złożone w obecności duchownego"

23 Urzędowy formularz każdego z tych zaświadczeń obejmuje 2 strony.

24 Szerzej: Tomkiewicz, Świto 2018.

25 Zob. art. 81 ust. 2 p.a.s.c.

26 Okres ważności tego zaświadczenia wynosi 6 miesięcy od daty wystawienia (art. $4^{1} \S 2$ k.r.o.). 
(tzw. „Zaświadczenie o zawartym małżeństwie”), które sporządzane jest przez podmiot wyznaniowy występujący w imieniu jednostki organizacyjnej kościoła albo innego związku wyznaniowego, w której zawarto małżeństwo, zaświadczające w sposób urzędowy, że oświadczenia o zawarciu małżeństwa zostały złożone wobec uprawnionego podmiotu urzędowego ${ }^{27}$.

Aby kierownik USC mógł dokonać rejestracji małżeństwa zawartego w formie wyznaniowej musi otrzymać prawidłowe ,Zaświadczenie o zawartym małżeństwie", to jest takie, które czyni zadość warunkom formalnym określonym w art. 87 ust. 3 pkt 1-5 p.a.s.c. oraz sporządzone zostało na urzędowym formularzu, którego wzór określony został w rozporządzeniu MSW z dnia 29 stycznia 2015 r. ${ }^{28}$, i które zostało przekazane do urzędu stanu cywilnego w wymaganym przez k.r.o. 5-dniowym terminie, liczonym od dnia zawarcia małżeństwa ${ }^{29}$, chyba że nastąpiło działanie siły wyższej, która - jako zjawisko nadzwyczajne i niemożliwe do zapobieżenia - przerywa bieg tego terminu ${ }^{30}$.

Zgodnie z art. 87 ust. 3 p.a.s.c. zaświadczenie o zawartym małżeństwie powinno zawierać w swej treści następujące dane:

- oznaczenie stron zawierających małżeństwo,

- oznaczenie świadków zawarcia małżeństwa,

- wskazanie daty i miejsca zawarcia małżeństwa,

- oznaczenie duchownego, wobec którego złożono oświadczenia o wstąpieniu w związek małżeński,

27 Formularz tego zaświadczenia w liczbie trzech egzemplarzy otrzymują nupturienci, którzy obowiązani są przekazać je przedstawicielowi jednostki organizacyjnej kościoła lub innego związku wyznaniowego, w którym zawarte będzie małżeństwo. Egzemplarze te, wypełnione przez duchownego, są przeznaczone dla osób, które zawarły małżeństwo, dla kościoła albo innego związku wyznaniowego, w którym zawarto małżeństwo oraz dla kierownika urzędu stanu cywilnego właściwego do sporządzenia aktu małżeństwa (zob. art. 81 ust. 3 p.a.s.c.).

28 Zob. załącznik $\mathrm{nr} 27$ do rozporządzenia Ministra Spraw Wewnętrznych z dnia 29 stycznia 2015 r. w sprawie wzorów dokumentów wydawanych z zakresu rejestracji stanu cywilnego, Dz. U. z 2015 r. poz. 194.

29 Zob. art. $8 \S 3$ k.r.o. oraz art. 10 ust. 1 pkt 3 in fine konkordatu.

30 O pojęciu siły wyższej zob. np. Czachórski 1998, 182. 
- wskazanie nazwy i adresu jednostki organizacyjnej kościoła lub innego związku wyznaniowego, w której sporządzane jest zaświadczenie,

- oznaczenie podmiotu wyznaniowego (duchownego) uprawnionego do sporządzenia niniejszego zaświadczenia (ze wskazaniem jego imienia, nazwiska i stanowiska służbowego).

Oznaczenie stron zawierających małżeństwo następuje poprzez wskazanie w zaświadczeniu ich imion i nazwisk oraz złożenie podpisów pod oświadczeniem o wstąpieniu w związek małżeński. Podobnie wygląda oznaczenie świadków zawarcia małżeństwa, których imiona i nazwiska oraz podpisy winny widnieć na formularzu zaświadczenia w miejscu poświadczającym fakt złożenia przez strony przedmiotowych oświadczeń. Datą zawarcia małżeństwa w formie wyznaniowej jest dzień, w którym strony złożyły na forum danego związku wyznaniowego - wobec uprawnionego duchownego - oświadczenia o zawarciu małżeństwa wyznaniowego wyrażając jednocześnie wolę zawarcia małżeństwa podlegającego prawu polskiemu. Miejscem zawarcia małżeństwa jest zaś kościół lub inny obiekt kultu, w którym zawierane są związki małżeńskie w danym kościele lub innym związku wyznaniowym. Z kolei oznaczenie duchownego uprawnionego do przyjęcia oświadczeń o wstąpieniu w związek małżeński następuje poprzez wskazanie na zaświadczeniu jego imienia i nazwiska oraz stanowiska zajmowanego w danym związku wyznaniowym. Musi to być jedno ze stanowisk wymienionych w części 1. wykazu stanowisk MSW z dnia 5 lutego 2015 r., których zajmowanie upoważnia do przyjmowania takich oświadczeń ${ }^{31}$. W podobny sposób następuje oznaczenie duchownego uprawnionego do sporządzenia niniejszego zaświadczenia, to jest poprzez wskazanie jego imienia i nazwiska oraz stanowiska, z zajmowaniem którego łączy się prawo do sporządzania takich zaświadczeń. Obecny wykaz stanowisk tych podmiotów ujęty został w części 2. załącznika do obwieszczenia MSW z dnia 5 lutego 2015 r. ${ }^{32}$ Nazwa i adres jednostki organizacyjnej kościoła lub innego związku wyznaniowego winna

31 Zob. załącznik do obwieszczenia MSW z dnia 5 lutego 2015 r. w sprawie ogłoszenia wykazu stanowisk, których zajmowanie upoważnia do przyjmowania oświadczeń o wstąpieniu w związek małżeński oraz sporządzania zaświadczeń stanowiących podstawę sporządzenia aktu małżeństwa zawartego w sposób określony w art. 1 § 2 i 3 Kodeksu rodzinnego i opiekuńczego, M.P. z 2015 r. poz. 230.

32 Tamże. 
wskazywać w jakiej parafii, zborze, gminie religijnej lub innej jednostce podziału administracyjnego danego kościoła lub innego związku wyznaniowego zawarto małżeństwo ${ }^{33}$.

Ponadto, choć nie wynika to z treści art. 87 ust. 3 p.a.s.c., na zaświadczeniu o zawartym małżeństwie powinna być wskazana nazwa związku wyznaniowego, w którym złożono oświadczenia o zawarciu małżeństwa. Wymóg ten nie został wyliczony w przepisie ustawowym, ujęty jest jednak w ministerialnym wzorze tego zaświadczenia. Wskazanie nazwy danego związku wyznaniowego jest zaś niezwykle istotne, zważywszy na to, że prawo do procedowania przy zawieraniu małżeństw cywilnych $\mathrm{w}$ formie wyznaniowej posiada obecnie tylko jedenaście związków wyznaniowych mających uregulowaną sytuację prawną w państwie ${ }^{34}$. Brak tej informa-

33 Warto przy tym zwrócić uwagę, że poprzednio obowiązujące przepisy rozporządzenia MSWiA z 1998 r., w którym określono wzór takiego zaświadczenia, przyjmowały, iż należało wskazać nazwę kościoła albo innego związku wyznaniowego, według którego prawa zostało zawarte małżeństwo (zob. załącznik nr 10 do rozporządzenia MSWiA z dnia 26 października 1998 r. w sprawie szczegółowych zasad sporządzania aktów stanu cywilnego, sposobu prowadzenia ksiąg stanu cywilnego, ich kontroli, przechowywania i zabezpieczania oraz wzorów aktów stanu cywilnego, ich odpisów, zaświadczeń i protokołów, Dz. U. z 1998 r. Nr 136, poz. 884). Wynikało z tego, że duchowny sporządzający zaświadczenie miał w nim wskazać nazwę związku wyznaniowego, w którym zawarto małżeństwo, a nie tylko nazwę jednostki organizacyjnej tego związku. Zob. Tunia 2006.

34 Zob. art. 15a ustawy z dnia 17 maja 1989 r. o stosunku Państwa do Kościoła Katolickiego w Rzeczypospolitej Polskiej (tekst jedn. Dz. U. z 2019 r. poz. 1347); art. 12a ustawy z dnia 4 lipca 1991 r. o stosunku Państwa do Polskiego Autokefalicznego Kościoła Prawosławnego (tekst jedn. Dz. U. z 2014 r. poz. 1726); art. 12a ustawy z dnia 13 maja 1994 r. o stosunku Państwa do Kościoła Ewangelicko-Augsburskiego w Rzeczypospolitej Polskiej (tekst jedn. Dz. U. z 2015 r. poz. 43); art. 8a ustawy z dnia 13 maja 1994 r. o stosunku Państwa do Kościoła Ewangelicko-Reformowanego w Rzeczypospolitej Polskiej (tekst jedn. Dz. U. z 2015 r. poz. 483 z późn. zm.); art. 11a ustawy z dnia 30 czerwca 1995 r. o stosunku Państwa do Kościoła Ewangelicko-Metodystycznego w Rzeczypospolitej Polskiej (tekst jedn. Dz. U. z 2014 r. poz. 1712); art. 10a ustawy z dnia 30 czerwca 1995 r. o stosunku Państwa do Kościoła Chrześcijan Baptystów w Rzeczpospolitej Polskiej (tekst jedn. Dz. U. z 2015 r. poz. 169); art. 10a ustawy z dnia 30 czerwca 1995 r. o stosunku Państwa do Kościoła Adwentystów Dnia Siódmego w Rzeczypospolitej Polskiej (tekst jedn. Dz. U. z 2014 r. poz. 1889); art. 9a ustawy z dnia 30 czerwca 1995 r. o stosunku Państwa do Kościoła Polskokatolickiego w Rzeczypospolitej Polskiej (tekst jedn. Dz. U. z 2014 r. poz. 1599); art. 9a ustawy z dnia 20 lutego 1997 r. o stosunku Państwa do gmin wyznaniowych żydowskich w Rzeczypospolitej Polskiej (tekst jedn. Dz. U. z 2014 r. poz. 1798); art. 8a 
cji $\mathrm{w}$ przepisie ustawowym stanowi istotne niedopatrzenie ustawodawcy, które należałoby uzupełnić. Poza nazwą związku wyznaniowego wzór zaświadczenia przewiduje również wskazanie, pod jaką pozycją zarejestrowano małżeństwo w kościelnej księdze małżeństw, a także w jakim urzędzie stanu cywilnego będzie sporządzany akt małżeństwa. Przewiduje też miejsce na odcisk pieczęci kościoła lub innego związku wyznaniowego ${ }^{35}$. Te trzy ostatnie wymogi nie są jednak na tyle istotne, by ich pominięcie uniemożliwiało sporządzenie przez kierownika USC aktu małżeństwa.

Co się zaś tyczy terminu przekazania zaświadczenia do USC, to w literaturze przedmiotu jest on różnie klasyfikowany, jako: zwykły, zawity, prekluzyjny lub przedawniający. Ustalenie charakteru tego terminu jest zaś istotne z uwagi na możliwość konwalidacji skutków jego uchybienia. Stąd za właściwy uznać należy ostatni ze wskazanych rodzajów, bowiem oceniając jego charakter patrzeć należy na skutki, jakie następują w razie nieprzekazania do USC zaświadczenia w ciągu 5 dni od zawarcia małżeństwa. Skutki te są zaś nieodwracalne, to znaczy w przypadku niedochowania tego terminu z innej przyczyny jak siła wyższa, organ administracji stanu cywilnego (kierownik USC) musi odmówić sporządzenia aktu małżeństwa. Terminu tego nie można przywrócić, bowiem ma on charakter nieprzywracalny. W literaturze przedmiotu mówi się o takich terminach, że są wyjątkowymi w naszym postępowaniu terminami nieprzywracanymi ${ }^{36}$.

Jak zaznaczono wyżej, podstawę sporządzenia aktu małżeństwa może stanowić również prawomocne postanowienie sądu o jego sporządzaniu, które w danym wypadku będzie stanowiło element przesłanki konstytutywnej sporządzenia aktu małżeństwa. Możliwość taka wynika $\mathrm{z}$ art. 2 ust. 1 p.a.s.c. stanowiącego o podstawach materialno-prawnych

ustawy z dnia 20 lutego 1997 r. o stosunku Państwa do Kościoła Starokatolickiego Mariawitów w Rzeczypospolitej Polskiej (tekst jedn. Dz. U. z 2015 r. poz. 14); art. 11a ustawy z dnia 20 lutego 1997 r. o stosunku Państwa do Kościoła Zielonoświątkowego w Rzeczypospolitej Polskiej (tekst jedn. Dz. U. z 2015 r. poz. 13).

35 Zob. załącznik nr 3 do rozporządzenia MSW z dnia 23 października 2015 r. zmieniającego rozporządzenie w sprawie wzorów dokumentów z zakresu rejestracji stanu cywilnego, Dz. U. z 2015 r. poz. 1751.

36 Uwaga powyższa poczyniona została w kontekście charakteru terminu złożenia wniosku o przywrócenie uchybionego terminu, którego upływ nie może być konwalidowany. Janowicz 1999, 185. Zob. też Tunia 2007. 
kształtujących stan cywilny osoby fizycznej, który odzwierciedlany jest w akcie stanu cywilnego oraz art. 4 ust. 1 p.a.s.c., w którym ustawodawca obliguje sądy m.in. do przekazywania do USC odpisów prawomocnych orzeczeń stanowiących podstawę sporządzenia aktu stanu cywilnego, jako że aktom tym przysługuje szczególna moc dowodowa ${ }^{37}$.

\section{REAKCJE ORGANU ADMINISTRACJI STANU CYWILNEGO W RAZIE NIEDOPEŁNIENIA ELEMENTÓW PRZESŁANKI SPORZĄDZENIA AKTU MAŁŻEŃSTWA}

Niedopełnienie wymogów związanych z prawidłowym sporządzeniem i przekazaniem do USC zaświadczenia o zawartym małżeństwie może rodzić różne reakcje kierownika USC, a co za tym idzie różne konsekwencje dla osób zawierających małżeństwo. W zależności od rodzaju uchybienia kierownik USC może:

1) wezwać do uzupełnienia braku formalnego zaświadczenia w wyznaczonym terminie, a w przypadku braku reakcji na wezwanie może pozostawić sprawę bez rozpoznania,

2) odmówić sporządzenia aktu małżeństwa, gdy zachodzą ustawowe okoliczności uzasadniające taką odmowę, lub

3) przeprowadzić postępowanie wyjaśniające.

\subsection{UZUPEŁNIENIE BRAKÓW FORMALNYCH}

Kierownik USC może wezwać do uzupełnienia braku formalnego w sytuacji, gdy brak ten jest usuwalny, a taki zachodzi w razie, gdy na zaświadczeniu brakuje:

- podpisu małżonków (lub jednego z nich),

- podpisu podmiotu urzędowego (duchownego) przyjmującego oświadczenia stron o wstąpieniu w związek małżeński,

37 Stanowią one bowiem wyłączny dowód zdarzeń w nich stwierdzonych (art. 3 p.a.s.c.). Zob. też: postanowienie Sądu Najwyższego z dnia 16 listopada 2016 r. (I CSK 807/15), Lex; Czajkowska (red.) 2014, 30; Czajkowska, Pachniewska 2005, 20-22; A. Gaffke, M. Gaffke $2019,74$. 
- podpisu podmiotu uprawnionego do sporządzenia zaświadczenia o zawartym małżeństwie, lub

- podpisu świadków (lub jednego z nich).

Brak trzech pierwszych z wymienionych podpisów to brak elementu przesłanki konstytutywnej zawarcia małżeństwa. W pierwszym przypadku dotyczy to niespełnienia elementu przesłanki konstytutywnej złożenia oświadczeń woli przez nupturientów ${ }^{38}$. Brak podpisów duchownego przyjmującego oświadczenia o wstąpieniu w związek małżeński oznacza niedopełnienie elementu przesłanki konstytutywnej udziału podmiotu urzędowego przy zawieraniu małżeństwa. Natomiast brak podpisu duchownego sporządzającego zaświadczenie o zawartym małżeństwie to „brak mocy prawnej zaświadczenia”, bowiem dopiero podpis tego duchownego nadaje zaświadczeniu charakter dokumentu urzędowego, potwierdzając prawdziwość zawartych w nim oświadczeń i danych. Brak ten należy do elementów przesłanki konstytutywnej (koniecznej) sporządzenia aktu małżeństwa. Inny charakter od powyższych ma brak podpisu świadków, bowiem ich podpis nie należy do żadnego z elementów przesłanek koniecznych zawarcia małżeństwa. Podpis ten ma jedynie charakter formalno-porządkowy. Jak wskazano bowiem - w zachowującym aktualność - wyroku SN z dnia 7 czerwca 1958 r. (II CR 293/58) brak podpisu świadków przy zawieraniu związku małżeńskiego nie powoduje nieważności złożonych przez małżonków oświadczeń ${ }^{39}$.

Uzupełnienia powyższych braków dokonać można na podstawie art. $64 \S 2$ k.p.a. ${ }^{40}$, zgodnie z którym należy wezwać wnoszącego podanie do ich usunięcia w terminie 7 dni z pouczeniem, że ich nieusunięcie spowoduje pozostawienie sprawy bez rozpoznania. Wprawdzie „wnoszącym podanie" jest w tym wypadku duchowny zobowiązany do przekazania do USC zaświadczenia o zawartym małżeństwie, jednakże nie jest on stroną postępowania mającego na celu zawarcie małżeństwa. Są nią małżonkowie, dlatego w przypadku braku na zaświadczeniu podpisu małżonków (małżonka) przepis art. $64 \S 2$ k.p.a. należy interpretować rozszerzająco, to

38 Mezglewski, Tunia 2007, 196; Mączyński 2003, 143.

39 OSPiKA z 1959 r. Nr 10, poz. 260.

40 Ustawa z dnia 14 czerwca 1960 r. - Kodeks postępowania administracyjnego, tekst jedn. Dz. U. z 2020 r. poz. 256 z późn. zm. 
znaczy kierownik USC powinien wezwać osoby (osobę) zawierające małżeństwo celem uzupełnienia danego braku. Natomiast w przypadku braku na zaświadczeniu podpisu duchownego przyjmującego oświadczenia stron lub podpisu duchownego sporządzającego zaświadczenie o zawartym małżeństwie kierownik USC winien wezwać odpowiednio tego duchownego, którego podpisu brakuje.

Niestawienie się osób wezwanych przez kierownika USC celem uzupełnienia powyższych braków skutkuje - jak wspomniano - pozostawieniem sprawy bez rozpoznania. Powoduje to, że złożone przez strony oświadczenia o wstąpieniu w związek małżeński pozostają prawnie bezskuteczne, a to z kolei stwarza niełatwą sytuację, bowiem złożone przez strony oświadczenia mają charakter bezwarunkowy, co oznacza, że nie mają one możliwości ich „,cofnięcia”. Brak podpisów na dokumencie stanowiącym element przesłanki konstytutywnej zawarcia małżeństwa uniemożliwia - zgodnie $\mathrm{z}$ art. $1 \S 2$ k.r.o. - jego rejestrację ${ }^{41}$, to zaś rodzi poważne konsekwencje zarówno dla zawierających małżeństwo, jak i innych podmiotów chcących wywodzić dla siebie określone skutki prawne związane z zawarciem tego związku.

\subsection{ODMOWA SPORZĄDZENIA AKTU MAŁŻEŃSTWA}

Odmowa sporządzenia aktu małżeństwa następuje w sytuacji, gdy kierownik USC stwierdzi naruszenia polegające na:

- zawarciu małżeństwa w formie wyznaniowej na forum wspólnoty wyznaniowej niemającej prawa do procedowania przy zawieraniu małżeństw w tej formie ${ }^{42}$;

41 Tunia 2017.

42 Jak zaznaczono wyżej, obecnie prawo do procedowania formy wyznaniowej zawarcia małżeństwa ma jedenaście (z piętnastu) związków wyznaniowych, które funkcjonują w państwie w oparciu o przepisy ustaw indywidualnych. Przedstawiciele czterech z tych wspólnot nie wystąpili o wprowadzenie do ich ustaw indywidualnych odpowiednich regulacji. Prawa tego nie mają również związki wyznaniowe posiadające wpis do rejestru kościołów i innych związków wyznaniowych działające na podstawie przepisów ustawy z dnia 17 maja 1989 r. o gwarancjach wolności sumienia i wyznania (tekst jedn. Dz. U. z 2017 r. poz. 1153), co w tym wypadku należy uznać za przejaw ich dyskryminacji. Szerzej: Zieliński 2012. 
- podpisaniu zaświadczenia o zawartym małżeństwie przez duchownego (podmiot wyznaniowy), który nie był uprawniony do przyjęcia oświadczeń o zawarciu małżeństwa, a więc podmiot, który nie zajmował stanowiska wymienionego w cz. 1. wykazu stanowisk MSW z 2015 r.;

- sporządzeniu zaświadczenia o zawartym małżeństwie przez nieuprawniony podmiot wyznaniowy (duchownego), tj. przez podmiot, który nie został wymieniony w cz. 2. wykazu stanowisk MSW z 2015 r., których zajmowanie upoważnia do sporządzenia takich zaświadczeń;

- przekazaniu do USC zaświadczenia o zawartym małżeństwie po upływie 5-dniowego terminu z innych przyczyn niż siła wyższa;

- nieprzekazaniu zaświadczenia do USC w ogóle.

W wymienionych wypadkach organ administracji stanu cywilnego obowiązany jest odmówić sporządzenia aktu małżeństwa wydając decyzję administracyjną. Czynności z zakresu rejestracji stanu cywilnego innych niż akty stanu cywilnego dokonuje się bowiem w formie decyzji administracyjnej albo czynności materialno-technicznej ${ }^{43}$. Art. 2 ust. 5 p.a.s.c. stanowi wyraźnie, że odmowa dokonania czynności z zakresu rejestracji stanu cywilnego ma formę decyzji administracyjnej. Decyzja ta nie jest ostateczna, bowiem - zgodnie z art. 89 ust. 1 pkt 4 i ust. 2 p.a.s.c. - w przypadku odmowy sporządzenia aktu małżeństwa kierownik USC zawiadamia na piśmie zainteresowaną osobę o tej odmowie. Osoba ta zaś może w terminie 14 dni od dnia doręczenia jej zawiadomienia złożyć wniosek do sądu właściwego ze względu na siedzibę USC o rozstrzygnięcie, czy przyczyny odmowy wskazane w zawiadomieniu uzasadniają odmowę dokonania czynności.

\subsection{POSTĘPOWANIE WYJAŚNIAJĄCE}

Art. 22 p.a.s.c. przewiduje, że kierownik USC - w razie uznania dowodów, na podstawie których ma sporządzić akt małżeństwa, za niewystarczające - może przeprowadzić postępowanie wyjaśniające w celu ustalenia

43 Zob. art. 2 ust. 5 p.a.s.c. Zob. też: A. Gaffke, M. Gaffke 2019, 74. 
stanu faktycznego, który miał być stwierdzony za pomocą złożonych dokumentów. Ustalenia tego może dokonać na podstawie dowodów materialnych, a także informacji uzyskanych od osobowych źródeł dowodowych, dlatego może on m.in. zwracać się do innych instytucji o otrzymanie dokumentu, na podstawie którego będzie mógł zweryfikować prawdziwość danych zawartych w zaświadczeniu, jak też wzywać osoby mogące zaświadczyć o faktach, na podstawie których ustalany jest stan faktyczny. Będą to przede wszystkim osoby uczestniczące czynnie w procedurze zawarcia małżeństwa (małżonkowie, świadkowie, duchowni), bowiem informacje dotyczące tych właśnie osób oraz realizowanych przez nich w tej procedurze zadań składają się na treść zaświadczenia stanowiącego podstawę sporządzenia aktu małżeństwa. Ponadto w dobie cyfryzacji zadań administracji publicznej i istniejących elektronicznych rejestrów danych osób fizycznych (i prawnych) kierownik USC może w pewnym zakresie weryfikować w trybie elektronicznym prawdziwość dowodów (informacji) stanowiących podstawę do sporządzenia aktu małżeństwa. Art. 21 p.a.s.c. stanowi zresztą wyraźnie, że kierownik USC dokonując czynności z zakresu rejestracji stanu cywilnego (a więc m.in. sporządzając akt małżeństwa) dokonuje sprawdzenia danych w elektronicznym rejestrze PESEL. Postępowanie wyjaśniające podejmowane może być bowiem nie tylko w celu sprawdzenia prawdziwości danych zawartych w zaświadczeniu (zaświadczeniach), ale także okoliczności wiążących się z jego terminowym przekazaniem. Kierownik USC może zatem sprawdzić np. czy okoliczność uchybiająca termin przekazania zaświadczenia do USC miała znamiona siły wyższej albo podjąć postępowanie wyjaśniające w związku z niedotarciem do USC w ogóle zaświadczenia o zawartym małżeństwie, które nadane zostało jako przesyłka polecona w urzędzie pocztowym ${ }^{44}$, zwracając się do duchownego o potwierdzenie treści utraconego zaświadczenia oraz dostarczenie dowodu nadania przesyłki ${ }^{45}$.

44 Chodzi oczywiście o przesyłkę nadaną w polskiej placówce pocztowej operatora wyznaczonego w rozumieniu ustawy z dnia 23 listopada 2012 r. - Prawo pocztowe (Dz. U. z 2018 r. poz. 2188 z późn. zm.).

45 Zob. art. 87 ust. 4 p.a.s.c. 


\section{SKUTKI NIESPORZĄDZENIA AKTU MAŁŻEŃSTWA ZAWIERANEGO W FORMIE WYZNANIOWEJ}

Niesporządzenie przez kierownika USC aktu małżeństwa rodzi poważne konsekwencje prawne, bowiem powoduje, że małżeństwo cywilne - mimo złożenia przez strony oświadczeń o wstąpieniu w związek małżeński oraz dopełnienia innych formalności - nie osiąga swych skutków. Powstaje zatem instytucja matrimonium non existens (małżeństwa nieistniejącego). Konsekwencje takiego zdarzenia dotknąć zaś mogą nie tylko samych zawierających małżeństwo, ale też inne osoby, które będą chciały wywodzić dla siebie określone skutki prawne wynikające z zawarcia tego związku (dzieci, powinowaci, przysposobieni, kontrahenci stron).

Wprawdzie k.r.o. nie zna terminu ,skutki małżeństwa”, jednakże na podstawie analizy odpowiednich przepisów prawa polskiego skutki takie można ustalić. Będzie to:

- niemożność zawarcia nowego małżeństwa (przeszkoda bigamii), (art. 13 k.r.o.);

- powstanie stosunku powinowactwa między krewnymi małżonków (art. 14 k.r.o.);

- nabycie nowego nazwiska (o ile strony złożyły takie oświadczenie), (art. 25 k.r.o.);

- domniemanie pochodzenia dziecka od męża matki (art. 62 k.r.o.);

- uzyskanie pełnoletniości przez małoletnią kobietę (art. $10 \S 2$ k.c. ${ }^{46}$ );

- powstanie między małżonkami małżeńskiej wspólnoty majątkowej (chyba że strony zawarły umowę o rozdzielności majątkowej (art. $31 \S 1$ k.r.o.), czego dalszym skutkiem jest m.in.:

- powstanie prawa do współposiadania oraz korzystania z rzeczy wchodzących w skład majątku wspólnego (art. $34^{1}$ k.r.o.);

- brak możliwości żądania podziału majątku wspólnego w czasie trwania wspólnoty majątkowej (art. 35 k.r.o.);

- obowiązek współdziałania w zarządzie majątkiem wspólnym (art. 36 k.r.o.);

46 Ustawa z dnia 23 kwietnia 1964 r. - Kodeks cywilny, tekst jedn. Dz. U. z 2019 r. poz. 1145 z późn. zm. 
- konieczność uzyskania zgody współmałżonka do dokonania czynności prawnych przekraczających zwykły zarząd majątkiem (art. 37 k.r.o.);

- ponoszenie odpowiedzialności za zobowiązania drugiego współmałżonka (art. 30 k.r.o.);

- możliwość wspólnego rozliczenia podatkowego małżonków, po spełnieniu warunków określonych $\mathrm{w}$ przepisach podatkowych (art. 6 u.p.d.o.f. $)^{47}$;

- prawo do dziedziczenia ustawowego po zmarłym współmałżonku (art. $931 \S 1$ k.c.);

- prawo do zachowku (art. 991 k.c.);

- możliwość sukcesji przedsiębiorstwa (prowadzonego w formie jednoosobowej działalności gospodarczej) zmarłego współmałżonka oraz wejście w jego prawa i obowiązki jako pracodawcy (art. 3 u.z.s.p. ${ }^{48}$ oraz art. $63^{2}$ k.p. ${ }^{49}$ );

- prawo do otrzymania określonych świadczeń finansowych, jakimi są m.in.:

- renta rodzinna i emerytura po zmarłym małżonku (art. 65-74 u.o.r.i.e.) $)^{50}$,

- zasiłek pielęgnacyjny (art. 16a u.ś.r.) oraz - w określonych okolicznościach - świadczenia pielęgnacyjne (art. 17 ust. 5 pkt 1 lit. au.s.r.) ${ }^{51}$.

Wskazany katalog skutków zawarcia małżeństwa ma jedynie charakter przykładowy, pozwalający ukazać rozpiętość problemów, jakie mogą zrodzić się w związku z niezarejestrowaniem przez kierownika USC mał-

47 Ustawa z dnia 26 lipca 1991 r. o podatku dochodowym od osób fizycznych, tekst jedn. Dz. U. z 2019 r. poz. 1387 z późn. zm.

48 Ustawa $\mathrm{z}$ dnia 5 lipca 2018 r. o zarządzie sukcesyjnym przedsiębiorstwa osoby fizycznej i innych ułatwieniach związanych z sukcesją przedsiębiorstw, Dz. U. z 2018 r. poz. 1629 z późn. zm.

49 Ustawa z dnia 26 czerwca 1974 r. - Kodeks pracy, tekst jedn. Dz. U. z 2020 r. poz. 1320 z późn. zm.

50 Ustawa z dnia z 17 grudnia 1998 r. o emeryturach i rentach z Funduszu Ubezpieczeń Społecznych, tekst jedn. Dz. U. z 2020 r. poz. 53 z późn. zm.

51 Ustawa z dnia 28 listopada 2003 r. o świadczeniach rodzinnych, tekst jedn. Dz. U. z 2020 r. poz. 111 z późn. zm. 
żeństwa zawieranego w formie wyznaniowej, a także jaki wpływ może to mieć na bezpieczeństwo obrotu prawnego.

Mając na uwadze wskazany katalog stwierdza się, iż skutki braku rejestracji małżeństwa mogą mieć zarówno charakter majątkowy, jak i niemajątkowy. Wydaje się, że skutki majątkowe są bardziej dotkliwe, bo generować mogą dużego rozmiaru szkody finansowe, których wyrównania (nie) małżonkowie mogą następnie dochodzić w drodze postępowania cywilnego. Szkody te mogą być związane m.in. z:

- koniecznością ponownego zawarcia związku małżeńskiego i wiążącymi się z tym nowymi nakładami finansowymi;

- niemożnością dziedziczenia majątku po zmarłym (nie)małżonku;

- niemożnością otrzymywania określonych świadczeń finansowych (renta rodzinna i emerytura po zmarłym małżonku, zasiłek pielęgnacyjny);

- niemożnością wspólnego opodatkowania przychodów przez (nie) małżonków;

- nieposiadaniem wspólnego majątku (nie)małżonków i nieosiąganiem z niego określonych pożytków (np. dochodów z wspólnego wynajętego mieszania, domu, działki czy dochodów z oszczędności zgromadzonych na wspólnym rachunku bankowym itd.).

Istnieją w praktyce sytuacje, że strony (nie-małżonkowie) dochodzą odszkodowań od jednostek organizacyjnych związków wyznaniowych (parafii), których przedstawiciele nie dopełnili obowiązków związanych z prawidłowym sporządzeniem i przekazaniem do USC zaświadczenia o zawartym małżeństwie, wskutek czego kierownik USC aktu takiego nie sporządził. Jako przykład warto odnotować wyrok z dnia 28 lutego 2018 r. (I C 2206/12) Sądu Okręgowego w Toruniu, w którym sąd ten zasądził od pozwanej parafii na rzecz powoda kwotę ponad $115000 \mathrm{zł} \mathrm{z} \mathrm{ustawowymi} \mathrm{odsetkami} \mathrm{tytułem} \mathrm{odszkodowania}$ za szkodę wynikłą z racji niezarejestrowania małżeństwa zawieranego w formie wyznaniowej z powodu uchybień obowiązków duchownego procedującego przy zawieraniu tego małżeństwa ${ }^{52}$. Innym przykładem wpływu braku rejestracji małżeństwa na bezpieczeństwo obrotu prawnego może być wyrok Wojewódzkiego Sądu Administracyjnego w Rze-

52 Zob. www.orzeczenia.ms.gov.pl, Legalis nr 2020702. 
szowie z dnia 6 listopada 2019 r. (II SA/Rz 919/19), w którym sąd odmówił przyznania prawa do otrzymania zasiłku opiekuńczego wnioskującemu, uzasadniając, że uprawnionym do specjalnego zasiłku opiekuńczego jest tylko taka osoba sprawująca opiekę na osobą niepełnosprawną określoną w art. 16a ust. 1 ustawy o świadczeniach rodzinnych, na której w świetle obowiązujących przepisów k.r.o. ciąży obowiązek alimentacyjny. Musi to być zatem krewny albo rodzeństwo, bądź też małżonek osoby wymagającej opieki ${ }^{53}$.

Odmowa rejestracji małżeństwa zawartego w formie wyznaniowej rodzić też może określone skutki o charakterze niemajątkowym, generując stan destabilizacji, w którym zarówno (nie)małżonkowie, jak i inne osoby, których skutki niezawarcia małżeństwa bezpośrednio dotyczą, doznawać mogą określonych - często trudnych do przewidzenia - krzywd lub strat moralnych. W takim bowiem wypadku:

- dzieci (nie)małżonków pozostają dziećmi pozamałżeńskimi;

- upada domniemanie pochodzenia dziecka od męża matki;

- (nie)małżonkowie nie mają prawa do wspólnego przysposobienia dziecka;

- (nie)małżonkowie nie mogą korzystać z określonych praw procesowych, jak np. prawa do odmowy składania zeznań w postępowaniach sądowych i administracyjnych;

- członkowie rodziny (nie)małżonków pozostają niespowinowaceni, zatem również nie mogą korzystać z określonych praw, np. nie mają prawa do korzystania z dni zwolnienia z pracy w razie zajścia okoliczności uzasadniających takie zwolnienie (ślub lub pogrzeb powinowatego) itd.

Tak więc wszystkie te sytuacje stanowią zagrożenie dla bezpieczeństwa obrotu prawnego, wprowadzając niepewność sytuacji prawnej (nie) małżonków, ich krewnych i innych osób obcych uczestniczących w obrocie prawnym, którego przedmiotem są relacje wynikające z niezawartego małżeństwa.

53 Zob. Lex nr 2744359. 


\section{WNIOSKI KOŃCOWE}

Przyjęta przez ustawodawcę polskiego konstrukcja przepisów uznająca za podstawę sporządzania aktu małżeństwa terminowo przekazane do USC ,zaświadczenie o zawartym małżeństwie” przez podmiot wyznaniowy jest zasadna, bowiem państwo nie ma innych instrumentów prawnych do zdyscyplinowania duchownych do terminowego przekazywania zaświadczeń do USC.

Istotnym czynnikiem eliminującym wiele z wymienionych zagrożeń mogłoby być wprowadzenie do przepisów prawa polskiego (p.a.s.c.) normy nakazującej kierownikowi USC powiadomienie małżonków o sporządzeniu aktu małżeństwa zawartego w formie wyznaniowej, co stawia się jako postulat de lege ferenda. W sytuacji bowiem, gdy warunek ten ma charakter przesłanki konstytutywnej, jego niespełnienie powoduje stan zagrożenia dla bezpieczeństwa obrotu prawnego oraz rodzi niebezpieczeństwo poważnych szkód i krzywd niematerialnych dla uczestników tego obrotu.

Proponuje się też de lege ferenda, aby do prawa dotyczącego zawierania małżeństw wyznaniowych wprowadzić regulację przewidującą w przypadku odmowy sporządzenia przez kierownika USC aktu małżeństwa zawartego w formie wyznaniowej z powodu uchybień leżących po stronie podmiotu wyznaniowego - prawo stron do skutecznego wnoszenia o sporządzenie tego aktu. Wszak to małżonkowie są stroną postępowania o rejestrację małżeństwa i to ich bezpośrednio dotyczą skutki niesporządzenia tego aktu. Dysponując egzemplarzem „własnego” zaświadczenia o zawartym małżeństwie mogliby na jego podstawie skutecznie wnosić o jego rejestrację przez kierownika USC. Rozwiązanie to pozwoliłoby uniknąć destabilizacji sytuacji osobistej, rodzinnej i finansowej małżonków oraz osób, których skutki niesporządzenia aktu bezpośrednio dotyczą. W demokratycznym państwie prawnym kształt prawa powinien bowiem dawać jego adresatom poczucie bezpiecznego uczestniczenia w obrocie prawnym. 


\section{BIBLIOGRAFIA}

Bielecki, Leszek, Jan Mojak, Agnieszka Żywicka (red.). 2019. Bezpieczeństwo prawne i bezpieczeństwo obrotu prawnego w Polsce. Lublin: Innovatio Press.

Czachórski, Witold. 1998. Zobowiazania. Zarys wykładu. Warszawa: Wydawnictwa Prawnicze PWN.

Czajkowska, Alicja (red.). 2014. Prawo o aktach stanu cywilnego z komentarzem. Przepisy wykonawcze i zwiazkowe oraz wzory dokumentów. Warszawa: Wolters Kluwer business.

Czajkowska, Alicja, Elżbieta Pachniewska. 2005. Prawo o aktach stanu cywilnego. Komentarz. Orzecznictwo. Wzory dokumentów i pism. Warszawa: LexisNexis. Dolecki, Henryk, Tomasz Sokołowski (red.). 2013. Kodeks rodzinny i opiekuńczy. Komentarz. Warszawa: Wolters Kluwer Polska.

Domański, Rafał. 2006. „Konstytutywny czy deklaratywny charakter sporządzenia aktu małżeństwa w przypadku małżeństwa konkordatowego". Państwo i Prawo 3: 86-99.

Gaffke, Aleksandra, Mirosława Gaffke. 2019. Vademecum kierownika urzędu stanu cywilnego. Warszawa: C.H. Beck.

Janowicz, Zbigniew. 1999. Kodeks postepowania administracyjnego. Komentarz. Warszawa: Wydawnictwa Prawnicze PWN.

Jędrejek, Grzegorz. 2019. Kodeks rodzinny i opiekuńczy. Komentarz aktualizowany. Warszawa: Lex/el.

Kochanowski, Janusz. 2007. „Wystąpienie podczas konferencji naukowej”. W: Język polskiej legislacji, czyli zrozumiałość przekazu a stosowanie praw. Materiaty z konferencji zorganizowanej przez Komisję Kultury i Środków Przekazu oraz Komisje Ustawodawcza, oprac. Anna Tietiajew-Różańska, 99-104. Warszawa: Kancelaria Sejmu.

Mączyński, Andrzej. 2003. „Konkordatowa forma zawarcia małżeństwa”. Rejent 10: $127-149$.

Mezglewski, Artur. 2009. „Realizacja przesłanek koniecznych przy zawieraniu małżeństwa w formie wyznaniowej”. W: Pro bono Reipublicae. Księga Jubileuszowa Profesora Michała Pietrzaka, red. Paweł Borecki, Andrzej Czohara, Tadeusz Jacek Zieliński, 325-332. Warszawa: LexisNexis.

Mezglewski, Artur. 2011. „Katalog przesłanek koniecznych zawarcia małżeństwa cywilnego w formie wyznaniowej”. W: Przestanki konieczne zawarcia matżeństwa cywilnego w formie wyznaniowej. Próba systematyzacji zagadnienia $w$ aspekcie wymogów formy religijnej, red. Anna Tunia, 11-22. Lublin: Wydawnictwo KUL. 
Mezglewski, Artur, Anna Tunia. 2007. Wyznaniowa forma zawarcia matżeństwa cywilnego. Warszawa: C.H. Beck.

Nowacki, Józef, Zygmunt Tabor. 1999. Wstę do prawoznawstwa. Katowice: Naukowa Oficyna Wydawnicza.

Pieprzny, Stanisław. 2012. Administracja bezpieczeństwa i porządku publicznego.

Rzeszów: Wydawnictwo Uniwersytetu Rzeszowskiego.

Pietrzykowski, Tomasz. 2003. „Czynności prawne z mocą wsteczną”. Radca Prawny 4: 64-76.

Potrzeszcz, Jadwiga. 2013. Bezpieczeństwo prawne z perspektywy filozofii prawa. Lublin: Wydawnictwo KUL.

Potrzeszcz, Jadwiga. 2015. „Podmiot bierny a podmiot czynny bezpieczeństwa prawnego". Teka Komisji Prawniczej. Oddziat PAN w Lublinie 8: 76-93.

Smyczyński, Tadeusz. 2005. Prawo rodzinne i opiekuńcze. Warszawa: C.H. Beck. Szadok-Bratuń, Aleksandra. 2013. Procedura zawierania matzeństwa , konkordatowego" w kontekście polskiego prawa administracyjnego. Wrocław: Uniwersytet Wrocławski, Prawnicza i Ekonomiczna Biblioteka Cyfrowa.

Tomkiewicz, Małgorzata, Lucjan Świto. 2018. „Zaświadczenie o braku okoliczności wyłączających zawarcie małżeństwa w procedurze matrimonium per procura". Studia z Prawa Wyznaniowego 21: 323-341.

Tunia, Anna. 2006. „Podstawa sporządzenia aktu małżeństwa zawartego w trybie art. 1 § 2 i 3 kodeksu rodzinnego i opiekuńczego". Roczniki Wydziału Nauk Prawnych i Ekonomicznych KUL 2: 251-277.

Tunia, Anna. 2007. „Charakter terminów stosowanych w procedurze zawierania małżeństwa cywilnego w formie wyznaniowej”. Studia z Prawa Wyznaniowego 10: 209-224.

Tunia, Anna. 2016. „Podmioty urzędowe procedujące przy zawieraniu małżeństw cywilnych w formie wyznaniowej w przypadku nupturientów pozbawionych wolności”. W: Wolność sumienia i religii osób pozbawionych wolności. Aspekty prawne i praktyczne, red. Jerzy Nikołajew, Konrad Walczuk, 285-298. Warszawa: Wydawnictwo Unitas.

Tunia, Anna. 2017. „Sytuacje niweczące skuteczność oświadczeń woli o zawarciu małżeństwa w demokratycznym państwie prawnym". Przeglad Prawno-Ekonomiczny 40: 22-39.

Wierciński, Jacek (red.). 2014. Kodeks rodzinny i opiekuńczy. Komentarz. Warszawa: Wolters Kluwer Polska.

Wojewoda, Michał. 2014. „Kilka uwag o definicji stanu cywilnego w nowej ustawie Prawo o aktach stanu cywilnego". Metryka. Studia z zakresu prawa osobowego rejestracji stanu cywilnego 2: 17-38. 
Zieliński, Tadeusz Jacek. 2011. „Stosowanie wyznaniowej formy zawarcia małżeństwa cywilnego poza Kościołem katolickim”. Państwo i Prawo 2: 19-33. Zieliński, Tadeusz Jacek. 2012. „Rozciągnięcie prawa procedowania wyznaniowej formy zawarcia małżeństwa cywilnego na wspólnoty wpisane do rejestru (propozycja de lege ferenda)". Przeglad Prawa Wyznaniowego 4: 169-176.

\section{THE IMPACT OF FAILURE TO REGISTER A RELIGIOUS MARRIAGE ON THE SECURITY OF LEGAL TRANSACTIONS}

Abstract

The paper focuses on the issue of the impact of failing to fulfil one of the necessary conditions for entering into a religious marriage, which is the issuance of a religious marriage certificate, on the security of legal transactions. To this end, the paper analyzes the essential components of this condition, which is a proper preparation and timely delivery of documents that are the basis for issuing a marriage certificate by a civil registry office. Next, possible reactions of a civil registration body are presented in relation to a failure to fulfil any of the individual components of this condition for marriage. Then, the paper discusses specific consequences of not issuing a religious marriage certificate, presenting situations in which spouses and other persons involved in legal transactions in connection with the marriage concluded will not be able to exercise the rights (and obligations) that would arise if a civil registrar issued the marriage certificate. From a de lege ferenda perspective, it is postulated that the current regulations on concluding a religious marriage should be amended, which will make it possible to ensure the security of legal transactions and, in many cases, eliminate non-material harm and damage resulting from a failure to enter into a marriage.

Key words: security; legal transactions; marriage; civil registration body; certificate; marriage certificate; marriage register 
